\title{
PERAN KEPUASAN KERJA MEMEDIASI PENGARUH PSYCHOLOGICAL CONTRACT TERHADAP TURNOVER INTENTION KARYAWAN
}

\section{Ni Putu Diah Suryadewi ${ }^{1}$ Ida Bagus Ketut Surya ${ }^{2}$}

\author{
${ }^{1,2}$ Fakultas Ekonomi dan Bisnis Universitas Udayana, Bali, Indonesia \\ email: d.suryadewi@yahoo.com
}

\begin{abstract}
ABSTRAK
Tujuan penelitian ini adalah untuk mengetahui Pengaruh Kepuasan Kerja Memediasi Psychological Contract Terhadap Turnover Intention. Penelitian ini dilakukan di The Samaya Ubud Luxury Villas. Jumlah sampel dalam penelitian ini sebanyak 58 orang karyawan pada housekeeping department, khususnya sampling jenuh. Pengumpulan data dilakukan dengan wawancara dan kuesioner. Teknik analisis yang digunakan adalah path analysis. Berdasarkan hasil analisis menunjukkan bahwa psychological contract berpengaruh negatif dan signifikan terhadap turnover intention, kepuasan kerja berpengaruh negatif dan signifikan terhadap turnover intention, psychological contract berpengaruh positif dan signifikan terhadap kepuasan kerja, serta kepuasan kerja secara parsial memediasi psychological contract terhadap turnover intention pada karyawan housekeeping department The Samaya Ubud Luxury Villas.
\end{abstract}

Kata kunci: psychological contract, kepuasan kerja, turnover intention

\begin{abstract}
The purpose of this study was to determine the Effect of Job Satisfaction Mediating Psychological Contracts on Turnover Intention. This research was conducted at The Samaya Ubud Luxury Villas. The number of samples in this study were 58 employees in the housekeeping department, especially saturated sampling. Data collection was carried out by interview and questionnaire. The analysis technique used is path analysis. Based on the results of the analysis shows that psychological contract has a negative and significant effect on turnover intention, job satisfaction has a negative and significant effect on turnover intention, psychological contract has a positive and significant effect on job satisfaction, and job satisfaction partially mediates psychological contract on turnover intention in housekeeping department employees The Samaya Ubud Luxury Villas.

Keywords: psychological contract, job satisfaction, turnover intention
\end{abstract}




\section{PENDAHULUAN}

Sumber Daya Manusia (SDM) merupakan hal utama yang dibutuhkan di dalam suatu organisasi. Sumber daya manusia merupakan aset perusahaan yang sangat penting karena sumber daya manusia selalu dibutuhkan dalam setiap proses produksi baik barang maupun jasa, dan dapat mempengaruhi keberhasilan suatu organisasi (Astitiani \& Sintaasih, 2019). Fenomena yang sering muncul saat ini adalah faktor ketidakpuasan pada tempat kerja sehingga menimbulkan keinginan karyawan untuk keluar dari organisasi. Salah satu aspek yang harus diperhatikan pada suatu organisasi adalah tingkat turnover intention atau keinginan untuk keluar dari organisasi yang dirasakan karyawan, karena jika tidak diperhatikan akan menimbulkan dampak negatif bagi organisasi (Utomo \& Prasetio, 2019).

Turnover intention menunjukkan seberapa niat karyawan untuk keluar dari organisasi (Mudiartha et al., 2015). Turnover intention adalah suatu keadaan dimana karyawan memiliki niat yang dilakukan secara sadar untuk mencari suatu pekerjaan lain sebagai alternatif di organisasi yang berbeda (Susilo \& Satrya, 2019). Turnover intention merupakan masalah yang sering timbul pada sebuah organisasi yang menyangkut keinginan keluarnya karyawan (Ksama \& Wibawa, 2016). Turnover Intention adalah kecenderungan dimana seorang individu memiliki suatu keinginan dalam meninggalkan perusahaan dan juga dapat diartikan sebagai niat karyawan untuk keluar dari perusahaan, dalam bentuk pengunduran diri maupun pemberhentian (Rarasanti \& Suana, 2016). Turnover intention mengacu pada niat karyawan untuk mencari alternatif pekerjaan lain (Nasution, 2017).

Tabel 1.

Jumlah Karyawan Housekeeping Department The Samaya Ubud Luxury Villas yang keluar pada Tahun 2018

\begin{tabular}{cccccc}
\hline Bulan & $\begin{array}{c}\text { Jumlah } \\
\text { Karyawan } \\
\text { Awal } \\
\text { Bulan } \\
\text { (orang) } \\
(\mathbf{1})\end{array}$ & $\begin{array}{c}\text { Jumlah } \\
\text { Karyawan } \\
\text { Akhir } \\
\text { Bulan } \\
\text { (orang) } \\
(\mathbf{2})\end{array}$ & $\begin{array}{c}\text { Jumlah } \\
\text { Karyawan } \\
\text { Masuk } \\
\text { (orang) } \\
(\mathbf{3})\end{array}$ & $\begin{array}{c}\text { Jumlah } \\
\text { Karyawan } \\
\text { Keluar } \\
\text { (orang) } \\
\mathbf{( 4 )}\end{array}$ & $\begin{array}{c}\text { Turnover } \\
\text { Karyawan } \\
\mathbf{( 5 )}\end{array}$ \\
\hline Januari & 49 & 54 & 9 & 4 & $(4)$ \\
Februari & 54 & 55 & 6 & 5 & $7,77 \%$ \\
Maret & 55 & 53 & 5 & 7 & $9,17 \%$ \\
April & 53 & 56 & 8 & 5 & $12,96 \%$ \\
Mei & 56 & 56 & 5 & 5 & $8,17 \%$ \\
Juni & 56 & 54 & 4 & 6 & $10,91 \%$ \\
Juli & 54 & 56 & 6 & 4 & $7,27 \%$ \\
Agustus & 56 & 57 & 8 & 7 & $12,39 \%$ \\
September & 57 & 58 & 9 & 8 & $13,91 \%$ \\
Oktober & 58 & 57 & 6 & 7 & $12,17 \%$ \\
November & 57 & 60 & 9 & 6 & $10,26 \%$ \\
Desember & 60 & 58 & 6 & 8 & $13,56 \%$ \\
\hline
\end{tabular}

Sumber: Human Resources Departement The Samaya Ubud Luxury Villas, 2018

Penelitian ini dilakukan di The Samaya Ubud Luxury Villas. The Samaya Ubud Luxury Villas merupakan villa yang bernaung di dalam PT. Grahawita 
Santika. The Samaya Ubud Luxury Villas menjalankan segala aktivitas operasionalnya dengan baik, dan sumber daya manusianya dibutuhkan dalam jumlah yang tidak sedikit. Tingginya tingkat turnover karyawan pada The Samaya Ubud Luxury Villas menurut pihak Human Resources Department (HRD) berasal dari departemen housekeeping. Suatu perusahaan dapat dikategorikan memiliki turnover yang tinggi apabila persentase karyawan yang keluar dari perusahaan melebihi angka 10\% (Widjaja et al., 2008).

Tabel 1. menunjukkan turnover karyawan housekeeping department The Samaya Ubud Luxury Villas Tahun 2018 selama 5 bulan terakhir di atas $10 \%$. Turnover yang tinggi pada perusahaan akan berdampak kerugian bagi perusahaan karena turnover menimbulkan biaya perekrutan, biaya pelatihan, dan biaya yang dikeluarkan untuk mengisi posisi yang kosong di dalam perusahaan (Khan \& Du, 2014). Tabel 1. dapat diindikasikan bahwa terdapat masalah turnover karyawan disebabkan oleh adanya turnover intention yang dirasakan karyawan housekeeping department. Tingkat turnover karyawan housekeeping department yang berada diatas $10 \%$ berturut-turut selama 5 bulan terakhir dapat memungkinan akan adanya peningkatan turnover di bulan selanjutnya pada karyawan housekeeping department The Samaya Ubud Luxury Villas.

Berdasarkan hasil wawancara dengan pihak HRD The Samaya Ubud Luxury Villas karyawan housekeeping department yang keluar disebabkan karena adanya ketidakpuasan karyawan terhadap pekerjaannya serta berkeinginan untuk meninggalkan perusahaan dikarenakan karyawan tersebut sudah mendapatkan kesempatan kerja yang lebih baik di tempat lain. Hasil wawancara dengan 10 karyawan housekeeping department The Samaya Ubud Luxury Villas, karyawan memiliki keinginan untuk meninggalkan perusahaan karena harapan yang berasal dari dalam diri karyawan akan perjanjian hubungan timbal balik dengan perusahaan atau psychological contract belum dipenuhi oleh perusahaan. Karyawan berharap untuk mendapatkan reward berupa bonus di luar gaji pokok yang diterima ketika mereka melakukan pekerjaan melebihi jam kerja mereka, serta karyawan juga berharap untuk mendapatkan pelatihan untuk meningkatkan kemampuan (skill) mereka, sehingga karyawan merasa hubungan timbal balik secara emosional dengan perusahaan belum berjalan dengan baik. Karyawan juga menyatakan gaji yang diterima belum sesuai dengan pekerjaan yang telah mereka laksanakan, hal ini berdampak pada menurunnya kepuasan kerja yang dirasakan karyawan.

Human Resources Department The Samaya Ubud Luxury Villas menyatakan kepuasan kerja yang menurun pada karyawan housekeeping department dapat dilihat ketika karyawan dalam melaksanakan pekerjaannya secara tidak maksimal dan menimbulkan keluhan dari tamu yang menginap. Kepuasan kerja yang rendah dirasakan oleh karyawan jika berlangsung terus menerus berdampak pada niat karyawan untuk keluar dari perusahaan.

Berdasarkan data turnover karyawan housekeeping department The Samaya Ubud Luxury Villas, dilakukan pra-survei mengenai turnover intention karyawan housekeeping department pada The Samaya Ubud Luxury Villas. Pra-survei dilakukan dengan menyebar kuisioner kepada 10 karyawan housekeeping department. Hasil pra-survei disajikan pada Tabel 2. berikut. 
Tabel 2.

Data Turnover Intention Karyawan Housekeeping Department The Samaya Ubud Luxury Villas Hasil Pra-survei

\begin{tabular}{clcccccc}
\hline No. & \multicolumn{1}{c}{ Pernyataan } & STS & TS & AS & S & SS & Rata-rata \\
\hline 1 & $\begin{array}{l}\text { Saya tidak puas dengan pekerjaan saya } \\
\text { saat ini. }\end{array}$ & - & 1 & 2 & 5 & 2 & 3,80 \\
2 & $\begin{array}{l}\text { Saya berpikir untuk keluar dari perusahaan } \\
\text { saat ini. }\end{array}$ & - & - & - & 7 & 3 & 4,30 \\
3 & $\begin{array}{l}\text { Saya berkeinginan mencari pekerjaan baru } \\
\text { pada perusahaan lain. }\end{array}$ & - & - & 1 & 3 & 6 & 4,50 \\
4 & $\begin{array}{l}\text { Saya merasa pekerjaan baru pada } \\
\text { perusahaan yang lain akan lebih baik. }\end{array}$ & - & - & - & 5 & 5 & 4,50 \\
5 & $\begin{array}{l}\text { Saya memiliki niat untuk meninggalkan } \\
\text { perusahaan ini. }\end{array}$ & - & - & 1 & 6 & 3 & 4,20 \\
Total & - & $\mathbf{1}$ & $\mathbf{4}$ & $\mathbf{2 6}$ & $\mathbf{1 9}$ & $\mathbf{4 , 2 6}$ \\
\hline
\end{tabular}

Sumber: Data diolah, 2019

Keterangan:

$\begin{array}{ll}\text { Skor } 1-1,80 & \text { : Sangat Rendah } \\ \text { Skor } 1,81-2,60 & \text { : Rendah } \\ \text { Skor } 2,61-3,40 & \text { : Cukup Tinggi } \\ \text { Skor } 3,41-4,20 & \text { : Tinggi } \\ \text { Skor } 4,21-5 & \text { : Sangat Tinggi }\end{array}$

Dari Tabel 2. dapat diindikasikan bahwa niat untuk meninggalkan perusahaan pada karyawan housekeeping department The Samaya Ubud Luxury Villas dikategorikan sangat tinggi, hal ini dikarenakan hasil data pra-survei memperoleh nilai rata-rata total 4,26. Turnover Intention akan bekurang jika kebutuhan psychological contract seseorang dapat terpenuhi dengan baik (Mishra \& Kumar, 2017).

Psychological contract adalah persepsi karyawan tentang perwujudan dan kewajiban timbal balik terhadap perusahaan (Fujiasih, 2017). Psychological contract dalam organisasi mengacu pada keyakinan yang dipegang bersama oleh seorang karyawan dan pemberi kerja berdasarkan ketentuan perjanjian di antara mereka (Onuoha \& Idemudia, 2018). Psychological contract merupakan suatu kontrak antara karyawan dan organisasi yang membantu dalam menghasilkan kepuasan kerja dan dapat meningkatkan semangat karyawan dalam bekerja (Chaubey \& Bisht, 2016).

Psychological contract mengacu pada bagaimana karyawan memahami kewajibannya sendiri terhadap majikan serta kewajiban majikan terhadap diri mereka sendiri (Maia \& Bastos, 2019). Psychological contract adalah kesepakatan antara karyawan dan organisasi serta kesepakatan yang tergantung masing-masing pihak. Psychological contract berfokus pada harapan karyawan yang harus terpenuhi untuk mencapai kepuasan karyawan, ketika psychological contract dapat terpenuhi, maka kepuasan kerja karyawan semakin tinggi (Fujiasih, 2017).

Kepuasan kerja merupakan sumber penting untuk dijadikan suatu dorongan karyawan dalam bekerja (Siengthai \& Pila-Ngarm, 2016). Kepuasan kerja 
didefinisikan sebagai keadaan menyenangkan atau emosi positif yang dihasilkan dari penilaian pekerjaan atau pengalaman kerja seseorang (Kristianto, 2017). Kepuasan kerja merupakan keadaan emosi yang senang atau emosi positif yang berasal dari penilaian pekerjaan atau pengalaman seseorang (Damayanti et al., 2018).

Kepuasan kerja merupakan suatu cerminan dari perasaan pegawai atau karyawan terhadap pekerjaannya (Purba et al., 2019). Prasetyo \& Marlina (2019) menyatakan kepuasan kerja sebagai kondisi yang menyenangkan atau tidak menyenangkan dan bagaimana para karyawan memandang pekerjaan mereka. Kepuasan kerja menggambarkan suatu perasaan positif seseorang tentang pekerjaan yang mereka lakukan (Belias et al., 2015).

Psychological contract yang tidak terpenuhi akan berdampak tidak baik bagi kinerja karyawan serta produktivitas organisasi serta dapat menimbulkan turnover intention pada karyawan (Malik \& Khalid, 2016). Semakin besar tingkat kepuasan seseorang dengan pekerjaannya, semakin besar pula keinginan seseorang tersebut untuk terus berada didalam perusahaan dan mengurungkan niat untuk melakukan turnover intention (Susilo \& Satrya, 2019). Kepuasan kerja karyawan yang dirasakan disebabkan oleh balas jasa (psychological contract) yang diterima dari hasil kerjanya untuk organisasi (Damayanti et al., 2018).

Pada penelitian ini kepuasan kerja dianalisis sebagai variabel pemediasi dalam hubungan psychological contract terhadap turnover intention karyawan. Hal tersebut didukung oleh hasil penelitian Mishra \& Kumar (2017) yang menyatakan bahwa kepuasan kerja memediasi psychological contract dan turnover intention, psychological contract yang terpenuhi maka otomatis kepuasan kerja akan meningkat, karyawan yang kebutuhannya dipenuhi oleh pemberi kerja maka tidak ada kemungkinan untuk berniat untuk pergi dari perusahaan atau organisasi tersebut atau melakukan turnover intention.

Teori yang melandasi penelitian ini yaitu Teori Pertukaran Sosial (social exchange theory). Social exchange theory yaitu hubungan seorang individu dengan individu lainnya, hubungan tersebut dapat dilihat dari penghargaan yang mereka dapatkan dan pengorbanan mereka lakukan (West \& Turner, 2008). Zhao et al. (2007) menunjukkan sesuai dengan social exchange theory, ketika suatu organisasi memenuhi maupun melakukan pelanggaran terhadap psychological contract, karyawan dapat membalasnya dengan setimpal, pemenuhan psychological contract dapat dilihat pada tingkat kepuasan kerja yang dirasakan karyawan, komitmen dari karyawan untuk tidak berniat melakukan turnover intention.

Psychological contract karyawan yang dapat dipenuhi oleh perusahaan akan berdampak pada rendahnya turnover intention yang dirasakan karyawan begitu pula sebaliknya ketika psychological contract tidak dipenuhi, maka akan meningkatkan turnover intention (Malik \& Khalid, 2016). Mishra \& Kumar (2017) menyatakan psychological contract berpengaruh negatif terhadap turnover intention. Kebutuhan psychological contract dapat dipenuhi oleh perusahaan akan menurunkan niat untuk keluar yang dirasakan karyawan, maka psychological contract berpengaruh negatif pada turnover intention (Xiong et al., 2017). Psychological contract yang terpenuhi akan mengarah pada menurunnya turnover intention, ini menunjukan psychological contract berpengaruh negatif terhadap turnover intention (Aykan, 
2014). Pemenuhan psychological contract akan berhubungan negatif dengan turnover intention (van den Heuvel et al., 2017). Wardhani \& Santoso (2018) juga menyatakan psychological contract memiliki pengaruh negatif terhadap turnover intention. Berdasarkan hasil penelitian sebelumnya maka dapat dikemukakan hipotesis sebagai berikut.

$\mathrm{H}_{1}$ : Psychological Contract berpengaruh negatif terhadap turnover intention

Putra \& Putra (2019) menyatakan semakin tinggi tingkat kepuasan kerja, maka keinginan untuk meninggalkan perusahaan akan semakin rendah, ini mempunyai arti bahwa kepuasan kerja berpengaruh secara negatif dan signifikan terhadap turnover intention. Kepuasan kerja yang menurun menimbulkan efek negatif pada kesehatan fisik dan mental mereka sendiri dan dapat meningkatkan turnover intention (Heponiemi et al., 2014). Januartha \& Adnyani (2019) semakin tinggi kepuasan kerja dapat mengakibatkan menurunkan turnover intention begitu sebaliknya semakin rendah kepuasan kerja dapat meningkatkan turnover intention pada karyawan. Kepuasan kerja berpengaruh negatif signifikan terhadap turnover intention (Anshori, 2019). Dewi \& Sriathi (2019) dalam penelitiannya menyatakan bahwa kepuasan kerja berpengaruh negatif signifikan terhadap turnover intention, berarti semakin tinggi kepuasan kerja yang dirasakan, akan dapat menurunkan keinginan karyawan untuk keluar dari perusahaanya. Saeed et al. (2014) menemukan bahwa kepuasan kerja memiliki pengaruh negatif terhadap turnover intention. Putra \& Mujiati (2016)menunjukkan bahwa kepuasan kerja berpengaruh negatif terhadap turnover intention. (Hafeez, 2019)menyatakan kepuasan kerja berpengaruh negatif terhadap turnover intention. Berdasarkan hasil penelitian sebelumnya maka dapat dikemukakan hipotesis sebagai berikut.

$\mathrm{H}_{2}$ : Kepuasan Kerja berpengaruh negatif terhadap turnover intention

Behery et al. (2016) menjelaskan pada penelitiannya bahwa ketika psychological contract tidak terpenuhi maka kepuasan kerja karyawan akan menurun. Psychological contract yang dipenuhi menunjukkan hubungan yang kuat dan positif dengan kepuasan kerja (Duan et al., 2019). Fujiasih (2017) menyatakan terdapat hubungan yang signifikan antara psychological contract dengan kepuasan kerja karyawan yang artinya semakin terpenuhi psychological contract maka semakin tinggi kepuasan kerja karyawan. Rodwell et al. (2015)menyatakan bahwa kontrak psikologis yang dipenuhi berdampak terhadap kepuasan kerja yang meningkat. Psychological Contract karyawan memiliki pengaruh positif yang signifikan terhadap kepuasan kerja Xiong et al. (2017). Yonatan \& Djastuti (2018) mengemukakan bahwa psychological contract berpengaruh positif dan signifikan terhadap kepuasan kerja, semakin tinggi pemahaman karyawan atas psychological contract dan semakin tinggi psychological contract yang ditawarkan perusahaan akan meningkatkan kepuasan kerja karyawan. Román et al. (2014)menyatakan bahwa psychological contract memiliki pengaruh positif pada kepuasan kerja. Berdasarkan hasil penelitian sebelumnya maka dapat dikemukakan hipotesis sebagai berikut.

$\mathrm{H}_{3}$ : Psychological Contract berpengaruh positif terhadap kepuasan kerja

Psychological contract yang tidak dipenuhi dapat meningkatkan turnover intention melalui variabel kepuasan kerja (Duan et al., 2019). Sikap kerja seperti 
kepuasan kerja dan komitmen organisasi memediasi dampak dari psychological contract dan turnover intention (Hartmann \& Rutherford, 2015). Psychological contract muncul sebagai alat untuk mengukur niat karyawan untuk pergi (turnover intention), dimana dimediasi oleh kepuasan kerja (Behery et al., 2016). Kepuasan kerja secara signifikan memediasi pengaruh hubungan antara psychological contract dan turnover intention (Blomme et al., 2010). Kepuasan kerja mempunyai peran sebagai variabel mediasi dalam hubungan antara psychological contract dan turnover intention (Xie et al., 2015). Berdasarkan hasil penelitian sebelumnya maka dapat dikemukakan hipotesis sebagai berikut.

$\mathrm{H}_{4}$ : Kepuasan Kerja memediasi pengaruh psychological contract terhadap turnover intention.

\section{METODE PENELITIAN}

Penelitian ini dilakukan di The Samaya Ubud Luxury Villas yang beralamat di Banjar Baung, Desa Sayan, Ubud, Bali. Pemilihan lokasi penelitian ini didasarkan karena adanya fenomena turnover karyawan housekeeping department The Samaya Ubud Luxury Villas. Hal ini dapat dijadikan bahwa terdapat permasalahan mengenai turnover intention.

Populasi adalah kumpulan dari seluruh elemen (unit dan individu) sejenis dan dapat dibedakan berdasarkan obyek penelitian. Populasi dalam penelitian ini adalah 58 karyawan housekeeping department yang bekerja pada The Samaya Ubud Luxury Villas. Teknik sampling yang digunakan dalam penelitian ini adalah sampling jenuh, dikarenakan seluruh populasi pada penelitian ini digunakan sebagai sampel.

Analisis jalur digunakan dalam menganalisis hubungan antar variabel dengan tujuan mengetahui pengaruh langsung maupun tidak langsung variabel independen terhadap variabel dependen. Dasar dari perhitungan koefisian jalur adalah analisis korelasi dan regresi dalam perhitungannya menggunakan software dengan program SPSS 17.0 for windows.

\section{HASIL DAN PEMBAHASAN}

Responden dalam penelitian ini yaitu 58 karyawan departemen housekeeping di The Samaya Ubud Luxury Villas. Penelitian ini menggunakan sampel jenuh yang mana seluruh populasi dijadikan sampel. Kuesioner yang disebarkan sebanyak 58 kuesioner, namun terdapat 2 kuesioner atau 3,45 persen tidak kembali, sehingga total jumlah responden yang berpartisipasi sebanyak 56 responden dengan persentase tingkat pengembalian sebesar 96,55 persen. Jadi, karakteristik responden dalam penelitian ini merupakan profil dari 56 responden yang berpartisipasi dalam pengisian kuesioner. Profil responden yang terdapat dalam kuesioner terdiri dari jenis kelamin, tingkat usia, tingkat pendidikan terakhir, serta masa kerja selama berada di dalam perusahaan.

Tabel 3. menunjukkan terdapat empat karakteristik responden yaitu jenis kelamin, tingkat usia, tingkat pendidikan terakhir, serta masa kerja. Sebagian besar responden dalam penelitian ini berjenis kelamin laki-laki dengan keseluruhan sebanyak 38 orang dengan persentase 67,9 persen dan sisanya sebesar 32,1 persen 
sebanyak 8 orang berjenis kelamin perempuan, hal ini dikarenakan jam kerja perusahaan tidak hanya sampai sore namun sampai larut malam. Penelitian ini didominasi dengan responden yang berusia 21-25 tahun, faktor usia seorang karyawan dapat menunjang keberhasilan pencapaian tujuan perusahaan, pada usia 21-25 tahun seseorang mempunyai semangat kerja yang tinggi dan mampu menghasilkan kualitas kerja yang baik.

Tabel 3.

Karakteristik Responden Departemen Housekeeping TheSamaya Ubud Luxury Villas

\begin{tabular}{cccc}
\hline No. & Jenis kelamin & $\begin{array}{c}\text { Jumlah Responden } \\
\text { (Orang) }\end{array}$ & $\begin{array}{c}\text { Persentase } \\
\text { Responden }(\%)\end{array}$ \\
\hline 1 & Laki-laki & 38 & 67,9 \\
2 & Perempuan & 18 & 32,1 \\
& Total & 56 & 100 \\
\hline \multirow{2}{*}{ No. } & Usia & Jumlah Responden & Persentase \\
& & (Orang) & Responden $(\%)$ \\
\hline 1 & $<20$ & 21 & 37,5 \\
2 & $21-25$ & 32 & 57,1 \\
3 & $26-30$ & 3 & 5,4 \\
& Total & 56 & 100 \\
\hline \multirow{2}{*}{ No. } & Pendidikan Terakhir & Jumlah Responden & Persentase \\
& & (Orang) & Responden $(\%)$ \\
\hline 1 & SMP & 1 & 1,8 \\
2 & SMA & 11 & 19,6 \\
3 & DIiploma & 40 & 71,4 \\
4 & S1 & 4 & 100 \\
& Total & 56 & Persentase \\
\multirow{2}{*}{ No. } & Masa Kerja (tahun) & Jumlah Responden & (Orang) \\
\hline 1 & $<2$ & 11 & 19,6 \\
2 & $2-5$ & 27 & 32,1 \\
3 & $>5-8$ & 18 & 100 \\
\hline
\end{tabular}

Sumber: Data diolah, 2019

Pendidikan terakhir responden sebagian besar lulusan Diploma yaitu sebanyak 40 orang dengan persentase 71,4 persen dan persentase terendah pada pendidikan terakhir responden yaitu satu orang responden dengan persentase 1,8 persen menempuh pendidikan terakhir SMP, hal ini dikarenakan latar belakang pendidikan bukan hal utama dalam perekrutan, melainkan keahlian yang dimiliki oleh responden. Dilihat dari masa kerja responden menunjukkan karyawan departemen housekeeping The Samaya Ubud Luxury Villas didominasi karyawan yang bekerja diantara 2-5 tahun.

Validitas dapat dilakukan melalui pengukuran korelasi antar skor total seluruh item pernyataan. Korelasi tiap faktor dinyatakan positif dan besarnya lebih dari 0,3 maka faktor tersebut dapat dikatakan konstruk yang kuat.

Hasil uji validitas pada tabel 4 menunjukkan bahwa seluruh pernyataan dalam indikator pada variabel turnover intention, kepuasan kerja, dan psychological contract memiliki nilai koefisien korelasi dengan skor total seluruh item pernyataan 
lebih besar dari 0,3 . Hal ini menunjukkan butir-butir pernyataan yang terdapat dalam indikator tersebut telah memenuhi syarat uji validitas.

Tabel 4.

Hasil Uji Validitas

\begin{tabular}{|c|c|c|c|c|c|}
\hline \multirow[b]{2}{*}{ No. } & \multirow[b]{2}{*}{ Variabel } & \multicolumn{3}{|c|}{ Validitas } & \multirow[b]{2}{*}{ Keterangan } \\
\hline & & Item & $\begin{array}{c}\text { Korelasi } \\
\text { Item Total }\end{array}$ & Standar & \\
\hline \multirow[t]{3}{*}{1} & Turnover Intention (Y) & $\left(\mathrm{Y}_{1.1}\right)$ & 0,978 & 0,3 & Valid \\
\hline & & $\left(Y_{1.2}\right)$ & 0,983 & 0,3 & Valid \\
\hline & & $\left(\mathrm{Y}_{1.3}\right)$ & 0,977 & 0,3 & Valid \\
\hline \multirow[t]{5}{*}{2} & Kepuasan Kerja (M) & $\left(\mathrm{M}_{1.1}\right)$ & 0,911 & 0,3 & Valid \\
\hline & & $\left(\mathrm{M}_{1.2}\right)$ & 0,892 & 0,3 & Valid \\
\hline & & $\left(\mathrm{M}_{1.3}\right)$ & 0,904 & 0,3 & Valid \\
\hline & & $\left(\mathrm{M}_{1.4}\right)$ & 0,922 & 0,3 & Valid \\
\hline & & $\left(\mathrm{M}_{1.5}\right)$ & 0,911 & 0,3 & Valid \\
\hline \multirow[t]{2}{*}{3} & Psychological Contract (X) & $\left(\mathrm{X}_{1.1}\right)$ & 0,961 & 0,3 & Valid \\
\hline & & $\left(\mathrm{X}_{1.2}\right)$ & 0,959 & 0,3 & Valid \\
\hline
\end{tabular}

Sumber: Data diolah, 2019

Reliabilitas menunjukkan sejauh mana suatu pengukuran dapat menghasilkan data yang sama (konsisten) bila dilakukan pengukuran beberapa kali terhadap obyek yang sama. Nilai suatu instrumen dikatakan reliabel bila nilai Alpha Cronbach $\geq 0,6$. Tabel 5. menyajikan hasil uji reliabilitas instrumen penelitian.

Tabel 5.

Hasil Uji Reliabilitas

\begin{tabular}{clccc}
\hline No. & \multicolumn{1}{c}{ Variabel } & \multicolumn{2}{c}{ Reliabilitas } & Alpha \\
Cronbach & Standar & Keterangan \\
\hline 1 & Turnover Intention $(\mathrm{Y})$ & 0,978 & 0,6 & Reliabel \\
2 & Kepuasan Kerja $(\mathrm{M})$ & 0,944 & 0,6 & Reliabel \\
3 & Psychological Contract $(\mathrm{X})$ & 0,917 & 0,6 & Reliabel \\
\hline
\end{tabular}

Sumber: Data diolah, 2019

Hasil uji reliabilitas pada Tabel 5. menujukkan bahwa ketiga instrumen penelitian yaitu turnover intention, kepuasan kerja dan psychological contract memiliki nilai Alpha Cronbach lebih besar dari 0,6. Jadi dapat dinyatakan bahwa seluruh variabel telah memenuhi syarat reabilitas atau kehandalan sehingga dapat digunakan untuk melakukan penelitian.

Pada penelitian ini menggunakan teknik analisis jalur (path analysis). Analisis jalur digunakan dalam menganalisis hubungan antar variabel dengan tujuan mengetahui pengaruh langsung maupun tidak langsung variabel independen terhadap variabel dependen.

Perhitungan koefisien path dilakukan dengan analisis korelasi dan regresi melalui software dengan program SPSS 17.0 for Windows, diperoleh hasil yang ditunjukkan sebagai berikut. 
Tabel 6.

Hasil Analisis Jalur Persamaan Regresi 1

\begin{tabular}{|c|c|c|c|c|c|}
\hline \multirow[t]{2}{*}{ Model } & \multicolumn{2}{|c|}{$\begin{array}{c}\text { Unstandardized } \\
\text { Coefficients }\end{array}$} & \multirow{2}{*}{$\begin{array}{c}\text { Standardized } \\
\text { Coefficients } \\
\text { Beta } \\
\end{array}$} & \multirow[t]{2}{*}{$\mathbf{t}$} & \multirow[t]{2}{*}{ Sig. } \\
\hline & B & Std. Error & & & \\
\hline (Constant) & 0,390 & 0,188 & & 2,078 & 0,042 \\
\hline Psychological Contract (X) & 0,919 & 0,053 & 0,921 & 17,340 & 0,000 \\
\hline $\mathrm{R}^{2}$ & & & & & 0,848 \\
\hline F Hitung & & & & & 300,687 \\
\hline Sig. F & & & & & 0,000 \\
\hline
\end{tabular}

Sumber: Data diolah, 2019

Hasil analisis jalur substruktural 1 seperti yang disajikan pada Tabel 6 maka persamaan strukturalnya adalah sebagai berikut.

$$
\mathrm{M}=0,921 \mathrm{X}+\mathrm{e}_{1}
$$

Tabel 7.

Hasil Analisis Jalur Persamaan Regresi 2

\begin{tabular}{cccccc}
\hline Model & \multicolumn{2}{c}{$\begin{array}{c}\text { Unstandardized } \\
\text { Coefficients }\end{array}$} & $\begin{array}{c}\text { Standardized } \\
\text { Coefficients }\end{array}$ & t & Sig. \\
& B & Std. Error & Beta & & \\
\hline (Constant) & 6,764 & 0,330 & & 20,500 & 0,000 \\
Psychological Contract (X) & $-0,447$ & 0,230 & $-0,366$ & $-1,943$ & 0,000 \\
Kepuasan Kerja (M) & $-0,604$ & 0,230 & $-0,495$ & $-2,623$ & 0,011 \\
R $^{2}$ & & & & & 0,713 \\
F Hitung & & & & & 65,817 \\
Sig. F & & & & & 0,000 \\
\hline
\end{tabular}

Sumber: Data diolah, 2019

Hasil analisis jalur substruktural 2 seperti yang disajikan pada Tabel 7, maka persamaan strukturalnya adalah sebagai berikut.

$$
\mathrm{Y}=-0,366 \mathrm{X}-0,495 \mathrm{M}+\mathrm{e}_{2}
$$

Berdasarkan model substruktur 1 dan substruktur 2, maka dapat disusun model diagram jalur akhir. Sebelum menyusun diagram jalur akhir, terlebih dahulu menghitung nilai standar error sebagai berikut.

$$
\begin{aligned}
& \mathrm{Pe}_{\mathrm{i}}=\sqrt{1-R i^{2}} \\
& \mathrm{Pe}_{1}=\sqrt{1-R 1^{2}}=\sqrt{1-0,848}=0,390 \\
& \mathrm{Pe}_{2}=\sqrt{1-R 2^{2}}=\sqrt{1-0,713}=0,536
\end{aligned}
$$

Berdasarkan perhitungan pengaruh error $\left(\mathrm{Pe}_{\mathrm{i}}\right)$, didapatkan hasil pengaruh error $\left(\mathrm{Pe}_{1}\right)$ sebesar 0,390 dan pengaruh error $\left(\mathrm{Pe}_{2}\right)$ sebesar 0,536. Hasil koefisien determinasi total adalah sebagai berikut.

$$
\mathrm{R}^{2} \mathrm{~m} \quad=1-\left(\mathrm{Pe}_{1}\right)^{2}\left(\mathrm{Pe}_{2}\right)^{2}
$$




$$
\begin{aligned}
& =1-(0,390)^{2}(0,536)^{2} \\
& =1-(0,152)(0,287) \\
& =1-0,044 \\
& =0,956
\end{aligned}
$$

Nilai determinasi total sebesar 0,956 mempunyai arti bahwa sebesar 95,6 persen variasi turnover intention karyawan dipengaruhi oleh variasi psychological contract dan variasi kepuasan kerja, sedangkan sisanya 4,4 persen dijelaskan oleh faktor lain yang tidak dimasukkan ke dalam model.

Maka dapat dihitung besarnya pengaruh langsung dan pengaruh tidak langsung serta pengaruh total antar variabel. Perhitungan pengaruh antar variabel dirangkum dalam Tabel 8 . sebagai berikut.

Tabel 8.

Pengaruh Langsung dan Pengaruh Tidak Langsung serta Pengaruh Total Psychological Contract(X), Kepuasan Kerja(M), dan Turnover Intention(Y)

\begin{tabular}{cccc}
\hline $\begin{array}{c}\text { Pengaruh } \\
\text { Variabel }\end{array}$ & $\begin{array}{c}\text { Pengaruh } \\
\text { Langsung }\end{array}$ & $\begin{array}{c}\text { Pengaruh Tidak Langsung Melalui } \\
\text { Kepuasan Kerja }(\mathbf{M})\left(\boldsymbol{\beta}_{\mathbf{3}} \times \boldsymbol{\beta}_{\mathbf{2}}\right)\end{array}$ & $\begin{array}{c}\text { Pengaruh } \\
\text { Total }\end{array}$ \\
\hline $\mathrm{X} \rightarrow \mathrm{Y}$ & $-0,366$ & $-0,456$ & $-0,822$ \\
$\mathrm{M} \rightarrow \mathrm{Y}$ & $-0,495$ & - & $-0,495$ \\
$\mathrm{X} \rightarrow \mathrm{M}$ & 0,921 & - & 0,921 \\
\hline
\end{tabular}

Sumber: Data diolah, 2019

Tabel 8. menunjukkan pengaruh langsung variabel Psychological Contract terhadap Turnover Intention sebesar -0,366. Pengaruh langsung variabel Kepuasan Kerja terhadap Turnover Intention sebesar -0,495 dan pengaruh langsung Psychological Contract terhadap Kepuasan Kerja adalah sebesar 0,921. Hal ini berarti bahwa variabel Turnover Intention lebih besar dipengaruhi oleh Kepuasan Kerja dari Psychological Contract. Sedangkan pengaruh tidak langsung variabel Psychological Contract terhadap Turnover Intention melalui Kepuasan Kerja sebesar -0,456. Jadi pengaruh total variabel Psychological Contract terhadap Turnover Intention melalui Kepuasan Kerja adalah sebesar -0,822. Dapat disimpulkan bahwa lebih besar total pengaruh Psychological Contract terhadap Turnover Intention yang melalui Kepuasan Kerja, daripada pengaruh langsung Psychological Contract terhadap Turnover Intention tanpa melalui variabel Kepuasan Kerja.

Model regresi dikatakan model yang baik digunakan jika model tersebut bebas dari asumsi klasik statistik. Hasil uji asumsi klasik yang dilakukan pada penelitian ini adalah uji normalitas dan uji heteroskedastisitas. Hasil uji asumsi klasik diolah dengan bantuan software SPSS 22.0 for Windows disajikan sebagai berikut.

Uji normalitas bertujuan untuk mengetahui apakah residual dari model regresi yang dibuat berdistribusi normal atau tidak. Untuk menguji apakah data yang akan digunakan dalam model regresi berdistribusi normal atau tidak dapat dilakukan dengan menggunakan uji Kolmogrov Smirnov. Apabila koefisien Asymp. Sig. (2tailed) lebih besar dari 0,05 maka data tersebut dikatakan berdistribusi normal. 
Tabel 9.

Normalitas Struktur 1

\begin{tabular}{lc}
\hline & Unstandardized Residual \\
\hline $\mathrm{N}$ & 56 \\
Kolmogorov-Smirnov $Z$ & 1,080 \\
Asymp.Sig. (2-tailed) & 0,194 \\
\hline Sumber Dat
\end{tabular}

Sumber: Data diolah, 2019

Tabel 9. menunjukkan bahwa nilai Kolmogorov Smirnov (K-S) sebesar 1,080, sedangkan nilai Asymp.Sig. (2-tailed) sebesar 0,194. Hasil tersebut mengindikasikan bahwa model persamaan regresi tersebut berdistribusi normal karena nilai Asymp.Sig. (2-tailed) lebih besar dari nilai alpha 0,05.

Tabel 10.

Normalitas Struktur 2

\begin{tabular}{lc}
\hline & Unstandardized Residual \\
\hline $\mathrm{N}$ & 56 \\
Kolmogorov-Smirnov $Z$ & 0,471 \\
Asymp.Sig. (2-tailed) & 0,979 \\
\hline
\end{tabular}

Sumber: Data diolah, 2019

Tabel 10. menunjukkan bahwa nilai Kolmogorov Smirnov (K-S) sebesar 0,471, sedangkan nilai Asymp.Sig. (2-tailed) sebesar 0,979. Hasil tersebut mengindikasikan bahwa model persamaan regresi tersebut berdistribudi normal karena nilai Asymp.Sig. (2-tailed) lebih besar dari nilai alpha 0,05.

Uji heteroskedastisitas bertujuan untuk mengetahui apakah dalam model regresi terjasi ketidaksamaan varians dari residual satu pengamatan ke pengamatan yang lain. Pengujian ini dilakukan dengan uji Glejser. Jika nilai signifikansinya diatas 0,05 maka tidak mengandung gejala heteroskedastisitas.

Tabel 11.

Hasil Uji Heteroskedastisitas Struktur 1

\begin{tabular}{cccccc}
\hline Model & \multicolumn{2}{c}{ Unstandardized } & Standardized & & \\
& Coefficients & Coefficients & t & Sig \\
& B & $\begin{array}{c}\text { Std. } \\
\text { Error }\end{array}$ & Beta & & \\
\hline 1 (Constant) & 0,320 & 0,126 & & 2,544 & 0,014 \\
Psychological Contract & $-0,018$ & 0,036 & $-0,069$ & $-0,510$ & 0,612 \\
\hline
\end{tabular}

Sumber: Data diolah, 2019

Tabel 11. dapat dilihat bahwa nilai signifikansi dari variabel psychological contract sebesar 0,612. Nilai tersebut lebih besar dari 0,05 yang berarti tidak terdapat pengaruh antara variabel bebas terhadap absolute residual. Dengan demikian, model yang dibuat tidak mengandung gejala heteroskedastisitas.

Tabel 12. dapat dilihat bahwa nilai signifikansi dari variabel psychological contract, dan kepuasan kerja masing-masing sebesar 0,058 dan 0,119 . Nilai tersebut lebih besar dari 0,05 yang berarti tidak terdapat pengaruh antara variabel bebas terhadap absolute residual. Dengan demikian, model yang dibuat tidak mengandung gejala heteroskedastisitas. 
Tabel 12.

Hasil Uji Heteroskedastisitas Struktur 2

\begin{tabular}{|c|c|c|c|c|c|}
\hline \multirow{2}{*}{ Model } & \multicolumn{2}{|c|}{$\begin{array}{l}\text { Unstandardized } \\
\text { Coefficients }\end{array}$} & \multirow{2}{*}{$\begin{array}{c}\begin{array}{c}\text { Standardized } \\
\text { Coefficients }\end{array} \\
\text { Beta }\end{array}$} & \multirow{2}{*}{$\mathbf{t}$} & \multirow{2}{*}{ Sig } \\
\hline & B & $\begin{array}{l}\text { Std. } \\
\text { Error }\end{array}$ & & & \\
\hline 1 (Constant) & 0,600 & 0,198 & & 3,035 & 0,004 \\
\hline Psychological Contract & $-0,267$ & 0,138 & $-0,658$ & $-1,938$ & 0,058 \\
\hline Kepuasan Kerja & 0,219 & 0,138 & 0,537 & 1,583 & 0,119 \\
\hline
\end{tabular}

Sumber: Data diolah, 2019

Pengujian hipotesis mediasi dapat dilakukan dengan Uji Sobel (Sobel Test). Uji sobel digunakan untuk menguji kekuatan pengaruh tidak langsung variabel psychological contract $(\mathrm{X})$ ke variabel turnover intention $(\mathrm{Y})$ melalui variabel kepuasan kerja (M). Bila nilai Z lebih besar dari 1,96 maka variabel mediator dinilai secara signifikan memediasi hubungan antara variabel terikat dan variabel bebas. Hasil Uji Sobel disajikan sebagai berikut.

$$
Z=\frac{\mathrm{ab}}{\sqrt{b^{2} \mathrm{~S} a^{2}+a^{2} \mathrm{~S} b^{2}+\mathrm{S} a^{2} \mathrm{~S} b^{2}}}
$$

Keterangan:

$$
\begin{aligned}
& \mathrm{a}=0,921 \\
& \mathrm{Sa}=0,053 \\
& \mathrm{~b}=0,495 \\
& \mathrm{Sb}=0,230
\end{aligned}
$$

$\mathrm{Z}=\frac{0,921 \times 0,495}{\sqrt{0,495^{2} 0,053^{2}+0,921^{2} 0,230^{2}+0,053^{2} 0,230^{2}}}$

$\mathrm{Z}=\frac{0,4559}{\sqrt{0,0007+0,0449+0,0001}}$

$\mathrm{Z}=\frac{0,4559}{\sqrt{0,0457}}$

$\mathrm{Z}=\frac{0,4559}{0,2137}$

$\mathrm{Z}=2,13$

Berdasarkan hasil perhitungan menunjukkan bahwa hasil tabulasi $\mathrm{Z}=2,13>$ 1,96 artinya kepuasan kerja secara signifikan memediasi hubungan antara psychological contract terhadap turnover intention karyawan.

VAF menjadi ukuran seberapa besar variabel pemediasi mampu menyerap pengaruh langsung yang sebelumnya signifikan dari model tanpa pemediasi. Untuk model pada Gambar 4.3, VAF dapat dihitung dengan (b x c)/(a + b x c). Apabila nilai VAF diatas 80 persen, maka menunjukkan peran $\mathrm{Y}_{1}$ sebagai pemediasi penuh (full mediation). Selanjutnya apabila nilai VAF di antara 20 persen hingga 80 persen, maka dapat dikategorikan sebagai pemediasi parsial (partial mediation). Namun, apabila nilai VAF kurang dari 20 persen, maka dapat dijelaskan bahwa hampir tidak ada efek mediasi.

$$
\begin{aligned}
\mathrm{VAF} & =(0,921 \times 0,495) /(0,366+(0,921 \times 0,495)) \\
& =0,456 / 0,822 \\
& =0,555 \text { atau } 55,5 \text { persen }
\end{aligned}
$$


Karena nilai VAF (55,5 persen) lebih dari 20 persen, maka dapat dijelaskan bahwa ada efek mediasi atau dengan kata lain Kepuasan Kerja secara parsial memediasi hubungan antara psychological contract terhadap turnover intention (partial mediation).

Berdasarkan pengujian hipotesis variabel psychological contract terhadap turnover intention, didapatkan hasil bahwa teori yang digunakan dalam penelitian ini yaitu social exchange theory terkonfirmasi. Social exchange theory menyatakan bahwa karyawan yang merasa psychological contract mereka terpenuhi, maka mereka memilih mengurungkan niat untuk melakukan turnover intention begitu pula sebaliknya ketika psychological contract tidak dipenuhi akan meningkatkan turnover intention (Zhao et al., 2007), hal tersebut sesuai dengan penelitian ini yang mendapatkan hasil psychological contract karyawan yang tidak terpenuhi menyebabkan niat karyawan untuk keluar dari perusahaan atau melakukan turnover intention semakin tinggi. Turnover intention karyawan departemen housekeeping The Samaya Ubud Luxury Villas dipengaruhi oleh belum terpenuhinya psychological contract yang dirasakan karyawan. Hasil ini mempunyai arti bahwa psychological contract berpengaruh negatif signifikan terhadap turnover intention.

Psychological contract yaitu harapan karyawan tentang perwujudan kewajiban timbal balik antara dirinya dengan perusahaan, harapan dari karyawan departemen housekeeping The Samaya Ubud Luxury Villas yaitu mendapatkan pelatihan untuk meningkatkan kemampuan mereka dan bonus diluar gaji pokok yang diterima ketika karyawan melakukan pekerjaan melebihi jam kerja mereka. Pemenuhan psychological contract perlu ditingkatkan agar menurunkan turnover intention yang dirasakan karyawan departemen housekeeping The Samaya Ubud Luxury Villas.

Penelitian ini memperkuat beberapa hasil penelitian sebelumnya yang dilakukan oleh Malik \& Khalid (2016)yang menyatakan ketika karyawan merasa psychological contract mereka dipenuhi oleh perusahaan maka turnover intention yang dirasakan akan rendah. Penelitian serupa juga dilakukan oleh Mishra \& Kumar (2017), Wardhani \& Santoso (2018), Xiong et al. (2017), Aykan (2014) dan van den Heuvel et al. (2017) yang memperoleh hasil bahwa psychological contract berpengaruh negatif terhadap turnover intention.

Pengujian hipotesis kepuasan kerja terhadap turnover intention dalam penelitian ini mendapatkan hasil kepuasan kerja karyawan yang rendah maka dapat diindikasikan semakin tinggi niat karyawan untuk keluar dari perusahaan, begitu pula sebaliknya semakin tinggi kepuasan kerja maka semakin rendah niat karyawan untuk meninggalkan perusahaan. Hasil tersebut menunjukkan bahwa kepuasan kerja berpengaruh negatif dan signifikan terhadap turnover intention. Turnover intention karyawan departemen housekeeping The Samaya Ubud Luxury Villas dipengaruhi oleh kepuasan kerja yang dirasakan karyawan.

Kepuasan kerja karyawan departemen housekeeping The Samaya Ubud Luxury Villas sebagian besar disebabkan oleh gaji yang belum sesuai dengan pekerjaan yang telah dilakukan sehingga menyebabkan karyawan memiliki keinginan untuk mencari pekerjaan baru pada perusahaan yang lain yang dirasa akan lebih baik. Kepuasan kerja karyawan departemen housekeeping The Samaya 
Ubud Luxury Villas perlu ditingkatkan untuk menurunkan turnover intention karyawan.

Penelitian ini dapat memperluas beberapa hasil penelitian sebelumnya yang dilakukan oleh Putra \& Putra (2019) menyatakan semakin tinggi tingkat kepuasan kerja, maka keinginan untuk meninggalkan perusahaan akan semakin rendah, ini mempunyai arti bahwa kepuasan kerja berpengaruh secara negatif dan signifikan terhadap turnover intention. Penelitian serupa juga dilakukan oleh Heponiemi et al. (2014), Januartha \& Adnyani (2019), Anshori (2019), Dewi \& Sriathi (2019), Saeed et al. (2014), Putra \& Mujiati (2016) dan Hafeez (2019) yang memperoleh hasil bahwa kepuasan kerja berpengaruh negatif terhadap turnover intention.

Berdasarkan pengujian hipotesis variabel psychological contract terhadap kepuasan kerja, diperoleh hasil bahwa teori yang digunakan pada penelitian ini yaitu social exchange theory terkonfirmasi. Teori tersebut menyatakan karyawan yang merasa psychological contract mereka terpenuhi, maka tingkat kepuasan kerja yang dirasakan lebih tinggi dan juga menyebabkan karyawan untuk tetap berkomitmen di organisasi yang mempekerjakan mereka (Deepthi \& Baral, 2013), hal tersebut sesuai dengan hasil penelitian yang memperoleh bahwa kepuasan kerja karyawan departemen housekeeping The Samaya Ubud Luxury Villas dipengaruhi oleh terpenuhinya psychological contract yang dirasakan karyawan, ini menunjukkan bahwa psychological contract berpengaruh positif dan signifikan terhadap kepuasan kerja, dapat diartikan psychological contract karyawan yang dipenuhi maka kepuasan kerja yang dirasakan akan semakin tinggi.

Psychological contract yang belum terpenuhi pada karyawan departemen housekeeping The Samaya Ubud Luxury Villas sebagian besar dapat dilihat dari karyawan yang belum mendapatkan pelatihan untuk meningkatkan kemampuan mereka serta karyawan yang belum pernah mendapatkan bonus ketika mereka melakukan pekerjaan melebihi jam kerja mereka. Pemenuhan psychological contract karyawan departemen housekeeping The Samaya Ubud Luxury Villas perlu ditingkatkan untuk meningkatkan kepuasan kerja karyawan.

Penelitian ini mendukung beberapa hasil penelitian sebelumnya yang dilakukan oleh Behery et al. (2016) menyatakan bahwa ketika psychological contract seseorang tidak terpenuhi maka kepuasan kerjanya akan menurun, begitu pula sebaliknya ketika psychological contract yang dipenuhi berdampak terhadap kepuasan kerja yang meningkat Rodwell et al. (2015). Penelitian serupa juga dilakukan oleh Fujiasih (2017), Duan et al. (2019), Xiong et al. (2017), Yonatan \& Djastuti (2018) dan Román et al. (2014) yang menyatakan bahwa psychological contract memiliki pengaruh positif pada kepuasan kerja.

Berdasarkan uji Sobel dalam penelitian ini, hasil yang diperoleh yaitu kepuasan kerja secara signifikan memediasi hubungan antara psychological contract terhadap turnover intention karyawan. Hasil penelitian ini memperkuat penelitian yang dilakukan oleh Blomme et al. (2010), Xie et al. (2015) dan Mohamed Behery et al. (2016) yang menyatakan kepuasan kerja mempunyai hubungan secara signifikan memediasi pengaruh hubungan antara psychological contract dan turnover intention. Penelitian serupa juga dilakukan oleh Duan et al. 
(2019) yang menyatakan psychological contract yang tidak dipenuhi dapat meningkatkan turnover intention melalui variabel kepuasan kerja.

Implikasi Praktis. Penelitian ini diharapkan mampu memberikan manfaat positif bagi semua pihak. Bagi perusahaan perlu memperhatikan kepuasan kerja karyawan agar karyawan tidak mempunyai niat untuk keluar dari perusahaan dengan cara memperhatikan kebutuhan psychological contract karyawan dengan pemberian pelatihan, dan reward berupa bonus demi tercapainya tujuan perusahaan. Implikasi Teoritis. Faktor yang mempengaruhi turnover intention dalam penelitian ini adalah psychological contract dan kepuasan kerja. Dalam penelitian ini kepuasan kerja merupakan variabel mediasi, karena mampu menunjukkan pengaruh psychological contract terhadap turnover intention. Penelitian ini dapat memberi dukungan empiris serta dapat dinyatakan memperkuat hasil penelitian sebelumnya.

\section{SIMPULAN}

Psychological contract berpengaruh negatif dan signifikan terhadap turnover intention. Hal ini memiliki arti bahwa semakin tinggi pemenuhan psychological contract karyawan maka turnover intetion karyawan akan menurun, begitu pula sebaliknya psychological contract yang tidak terpenuhi maka turnover intention karyawan akan meningkat. Kepuasan kerja berpengaruh negatif dan signifikan terhadap turnover intention. Hal ini menunjukkan kepuasan kerja karyawan yang tinggi akan menurunkan turnover intention pada karyawan, begitu pula sebaliknya kepuasan kerja yang dirasakan menurun akan menimbulkan niat untuk keluar dari perusahaan. Psychological contract berpengaruh positif dan signifikan terhadap kepuasan kerja. Hal ini mengindikasikan bahwa psychological contract karyawan yang dapat dipenuhi oleh perusahaan akan meningkatkan kepuasan kerja mereka, begitu pula sebaliknya psychological contract yang tidak terpenuhi atau menurun maka kepuasan kerja karyawan juga akan menurun. Kepuasan kerja secara parsial memediasi hubungan antara psychological contract terhadap turnover intention. Hal ini menunjukkan bahwa pengaruh psychological contract terhadap turnover intention diperkuat dengan masuknya kepuasan kerja sebagai mediator.

Pihak perusahaan hendaknya mampu mencegah karyawan agar tidak mempunyai niat untuk keluar dari perusahaan. Berdasarkan deskripsi jawaban responden terhadap turnover intention, niat karyawan untuk keluar dari perusahaan dikatakan cukup tinggi, maka perlu diperhatikan apa yang menyebabkan mereka mempunyai niat untuk keluar dari perusahaan. Dalam hal ini untuk menurunkan tingkat turnover intention karyawan, perusahaan harus mewujudkan kepuasan kerja mereka melalui pemenuhan psychological contract karyawan yang mampu meningkatkan kepuasan kerja mereka, sehingga dapat menurunkan niat karyawan untuk meninggalkan perusahaan.

Pihak perusahaan hendaknya mampu mewujudkan harapan yang berasal dari dalam diri karyawan akan hubungan timbal balik antara dirinya dengan perusahaan (psyhcological contract). Berdasarkan deskripsi jawaban responden terhadap psychological contract, nilai rata-rata paling rendah diantara yang lainnya terdapat pada dimensi "kontrak ekstrinsik". Dalam hal ini upaya yang dapat dilakukan perusahaan yaitu memberikan pelatihan kepada karyawan untuk meningkatkan 
kemampuan mereka serta pemberian reward berupa bonus ketika karyawan bekerja melebihi jam kerja mereka, pemberian reward tersebut diberikan agar karyawan merasa dihargai ketika sudah bekerja dengan baik dan secara langsung tingkat kepuasan kerja karyawan pun akan meningkat.

Kepuasan kerja karyawan juga perlu diperhatikan oleh perusahaan. Salah satu indikator kepuasan kerja yang memiliki nilai rata-rata terendah berdasarkan deskripsi jawaban responden yaitu indikator gaji. Pihak perusahaan perlu menyesuaikan gaji dengan pekerjaan yang telah dilaksanakan karyawan, dengan memperhatikan tingkat kepuasan kerja karyawan, perusahaan akan dapat menurunkan niat karyawan untuk meninggalkan perusahaan.

\section{REFERENSI}

Anshori, M.Y. 2019. Analisis Turnover Intention pada Karyawan Primebiz Hotel Surabaya. Jurnal Ekonomi dan Pariwisata, 14(1).

Astitiani, N.L.P.S. \& Sintaasih, D.K. 2019. Peran Mediasi Knowledge Sharing pada Pengaruh Quality of Work Life dan Kepuasan Kerja terhadap Kinerja Karyawan. Matrik: Jurnal Manajemen, Strategi Bisnis dan Kewirausahaan, $1-14$.

Aykan, E. 2014. Effects of perceived psychological contract breach on turnover intention: Intermediary role of loneliness perception of employees. ProcediaSocial and Behavioral Sciences, 150: 413-419.

Behery, M., Abdallah, S., Parakandi, M. \& Kukunuru, S. 2016. Psychological contracts and intention to leave with mediation effect of organizational commitment and employee satisfaction at times of recession. Review of International Business and Strategy, 26(2): 184-203.

Belias, D., Koustelios, A., Vairaktarakis, G. \& Sdrolias, L. 2015. Organizational culture and job satisfaction of Greek banking institutions. Procedia-Social and Behavioral Sciences, 175: 314-323.

Blomme, R.J., Van Rheede, A. \& Tromp, D.M. 2010. The use of the psychological contract to explain turnover intentions in the hospitality industry: A research study on the impact of gender on the turnover intentions of highly educated employees. The International Journal of Human Resource Management, 21(1): 144-162.

Chaubey, D.S. \& Bisht, S. 2016. Analysis of psychological contract and its relationship with job satisfaction: An empirical study. Splint International Journal of Professionals, 3(8): 92.

Damayanti, R., Hanafi, A. \& Cahyadi, A. 2018. Pengaruh kepuasan kerja terhadap kinerja karyawan (studi kasus karyawan non medis RS Islam Siti Khadijah Palembang).

Deepthi, U. \& Baral, R. 2013. Understanding the role of generational differences in 
psychological contract fulfillment and its impact on employees' cognitive responses. Review of HRM, 2: 74.

Dewi, P.S.A. \& Sriathi, A.A.A. 2019. Pengaruh Stres Kerja terhadap Turnover Intention yang Dimediasi oleh Kepuasan Kerja. E-Jurnal Manajemen, 8(6): 3646-3673.

Duan, X., Ni, X., Shi, L., Zhang, L., Ye, Y., Mu, H., Li, Z., Liu, X., Fan, L. \& Wang, Y. 2019. The impact of workplace violence on job satisfaction, job burnout, and turnover intention: the mediating role of social support. Health and quality of life outcomes, 17(1): 93.

Fujiasih, L. 2017. Hubungan Kontrak Psikologis dengan Kepuasan Kerja Pada Karyawan Tetap dan Karyawan Outsourcing di PT. Sucofindo (PERSERO) Sangatta, Kutai Timur, Kalimantan Timur. E-journal.psikologi.fisipunmul.ac.id., 5(3): 630-641.

Hafeez, M.M.I. 2019. Influence of Thriving and Job Satisfaction on Turn Over Intention: Mediating Role of Job Satisfaction. International Journal of Information, Business and Management, 11(3): 1-8. Tersedia di https://search.proquest.com/docview/2216868424?accountid=32506.

Hartmann, N.N. \& Rutherford, B.N. 2015. Psychological contract breach's antecedents and outcomes in salespeople: The roles of psychological climate, job attitudes, and turnover intention. Industrial Marketing Management, 51: 158-170.

Heponiemi, T., Kouvonen, A., Virtanen, M., Vänskä, J. \& Elovainio, M. 2014. The prospective effects of workplace violence on physicians' job satisfaction and turnover intentions: the buffering effect of job control. BMC health services research, 14(1): 19.

van den Heuvel, S., Freese, C., Schalk, R. \& van Assen, M. 2017. How change information influences attitudes toward change and turnover intention: the role of engagement, psychological contract fulfillment, and trust. Leadership \& Organization Development Journal, 38(3): 398-418. Tersedia di https://search.proquest.com/docview/1886580245/fulltextPDF/A6B2FE3C2 0874623PQ/16? accountid=32506.

Januartha, A.A.G.A. \& Adnyani, I.G.A.D. 2019. Pengaruh Job Insecurity dan Kepuasan Kerja terhadap Turnover Intention pada Karyawan Hotel. E-Jurnal Manajemen, 8(2): 588-615.

Khan, M.A.S. \& Du, J. 2014. An empirical study of turnover intentions in call centre industry of Pakistan. Journal of Human Resource and Sustainability Studies, 2(4): 206.

Kristianto, D. 2017. Pengaruh Kepuasan Kerja terhadap Kinerja Karyawan dengan Komitmen Organisasional sebagai Variabel Intervening (Studi pada RSUD Tugurejo Semarang). Jurnal Bisnis Strategi, 20(2): 52-63. 
Ksama, I.B.P.T. \& Wibawa, I.M.A. 2016. Pengaruh Leader-member Exchange, Role Stress Dan Perceived Organizational Support Terhadap Turnover Intention. E-Jurnal Manajemen, 5(10).

Maia, L.G. \& Bastos, A.V.B. 2019. Climbing the Ladder of Performance: Are Psychological Contract and Organizational Commitment Steps? BARBrazilian Administration Review, 16(1).

Malik, S.Z. \& Khalid, N. 2016. Psychological contract breach, work engagement and turnover intention: Evidence from banking industry in Pakistan. Pakistan Economic and Social Review, 54(1): 37.

Mishra, S. \& Kumar, P. 2017. Exploring the nexus between psychological contract and turnover intention: conceptual framework. Romanian Economic and Business Review, 12(1).

Mudiartha, U.I.W., Komang, A.I., Kartika, D.A.A.S. \& Sriathi, A.A.A. 2015. Pengaruh Keamanan Kerja pada Turnover Intention dengan Kepuasan Kerja Sebagai Variabel Pemediasi. Matrik: Jurnal Manajemen, Strategi Bisnis dan Kewirausahaan. Tersedia https://ojs.unud.ac.id/index.php/jmbk/article/view/14398.

Nasution, M.I. 2017. Pengaruh Stres Kerja, Kepuasan Kerja Dan Komitmen Organisasi Terhadap Turnover Intention Medical Representative. MIX: Jurnal Ilmiah Manajemen, 7(3).

Onuoha, C.U. \& Idemudia, E.S. 2018. Workplace deviance among public secondary school teachers: personality traits and perception of psychological contract breach as predictors. Journal of Gender, Information and Development in Africa (JGIDA), 7(Special Issue 1): 69-84.

Prasetyo, E.T. \& Marlina, P. 2019. Pengaruh Disiplin Kerja dan Kepuasan Kerja Terhadap Kinerja Karyawan. Jurnal Inspirasi Bisnis Dan Manajemen, 3(1): 21-30.

Purba, D.C., Lengkong, V.P.K. \& Loindong, S. 2019. Analisis Pengaruh Kepuasan Kerja, Motivasi Kerja dan Disiplin Kerja terhadap Kinerja Karyawan pada Perusahaan Umum Percetakan Negara Republik Indonesia Cabang Manado. Jurnal EMBA: Jurnal Riset Ekonomi, Manajemen, Bisnis dan Akuntansi, 7(1).

Putra, I.M.Y.D. \& Putra, M.S. 2019. Peran Kepuasan Kerja Memediasi Iklim Organisasi terhadap Turnover Intention. E-Jurnal Manajemen, 8(1): 323-351.

Putra, I.P.P. \& Mujiati, N.W. 2016. Pengaruh Kompetensi, Kompensasi Finansial dan Motivasi Kerja Pada Kepuasan Kerja Karyawan Take Japanese Restaurant Legian Kuta Badung Bali. E-Jurnal Manajemen, 5(1).

Rarasanti, I.A.P. \& Suana, I.W. 2016. Pengaruh Job Embeddedness, Kepuasan Kerja, dan Komitmen Organisasional terhadap Turnover Intention Karyawa. E-Jurnal Manajemen, 5(7). 
Rodwell, J., Ellershaw, J. \& Flower, R. 2015. Fulfill psychological contract promises to manage in-demand employees. Personnel Review, 44(5): 689701.

Román, J.P., Battistelli, A. \& Odoardi, C. 2014. Organizational respect as mediator between the ideological psychological contract and workers' job satisfaction: empirical findings from the social enterprise sector. Journal of Social entrepreneurship, 5(1): 107-122.

Saeed, I., Waseem, M., Sikander, S. \& Rizwan, M. 2014. The relationship of turnover intention with job satisfaction, job performance, leader member exchange, emotional intelligence and organizational commitment. International Journal of Learning and Development, 4(2): 242-256.

Siengthai, S. \& Pila-Ngarm, P. 2016. The interaction effect of job redesign and job satisfaction on employee performance. Evidence-based HRM: a Global Forum for Empirical Scholarship. Emerald Group Publishing Limited, hal.162-180. Tersedia di https://ojs.uajy.ac.id/index.php/modus/article/download/1703/1186.

Susilo, J. \& Satrya, I.G.B.H. 2019. Pengaruh Kepuasan Kerja terhadap Turnover Intention yang Dimediasi oleh Komitmen Organisasional Karyawan Kontrak. E-Jurnal Manajemen, 8(6): 3700-3729.

Utomo, K.H. \& Prasetio, A.P. 2019. Pengaruh Kepuasan Kerja terhadap Turnover Intention. ISEI Business and Management Review, 2(2): 5-12.

Wardhani, A.R. \& Santoso, C.B. 2018. Pengaruh Kontrak Psikologis Terhadap Intensi Keluar dengan Komitmen Afektif Sebagai Variabel Mediator. Jurnal Aplikasi Bisnis dan Manajemen (JABM), 4(3).

West, R. \& Turner, L.H. 2008. Pengantar teori komunikasi: analisis dan aplikasi. Jakarta: Salemba Humanika.

Widjaja, D.C., Fulbertus, M. \& DW, F.K. 2008. Analisis persepsi employee empowerment terhadap employee turnover intention di Hotel X, Kupang, Nusa Tenggara. Jurnal Manajemen Perhotelan, 4(2): 72-84.

Xie, X., Liu, H. \& Deng, H. 2015. Psychological Contract Breach and Turnover Intention: The Intermediary Role of Job Satisfaction. Open Journal of Business and Management, 3(4): 371.

Xiong, Z., Jianmu, Y.E. \& Pengju, W. 2017. Psychological contract and turnover intention of dispatched employees: Mediating effects of job satisfaction and organizational commitment. Revista de Cercetare si Interventie Sociala, 56: 19.

Yonatan, D. \& Djastuti, I. 2018. Analisis Pengaruh Kontrak Psikologis, Leader Member Exchange (LMX), dan Kepuasan Kerja Sebagai Variabel Intervening Terhadap Kinerja Karyawan. Jurnal Studi Manajemen Organisasi, 15(1): 16. 
E-Jurnal Manajemen, Vol. 9, No. 5, 2020 : 1717-1737

Zhao, H.A.O., Wayne, S.J., Glibkowski, B.C. \& Bravo, J. 2007. The impact of psychological contract breach on work-related outcomes: a meta-analysis. Personnel psychology, 60(3): 647-680. 